\title{
THE RESPONSE OF FJORD GLAGIERS TO CHANGES IN THE FIRN LIMIT
}

\author{
By J. H. Mercer \\ (Institute of Polar Studies, Ohio State University, Columbus, Ohio)*
}

\begin{abstract}
Glaciers in fjords almost always reach standstill positions at the fjord mouths or at changes in their width. Between such positions the terminus is usually advancing or retreating: the advance may be anomalous compared to glaciers on dry land in the vicinity, and the retreat may be catastrophically rapid. These peculiarities of fjord glaciers can be at least partly explained by considering conditions to be expected in an ideal fjord of constant width: the glacier cannot reach equilibrium by changing the extent of its ablation area or its calving terminus, and these cannot change their altitude with respect to sea-level in response to a rise or fall in the firn limit.
\end{abstract}

RÉsumé. Les glaciers s'écoulant dans des fjords atteignent presque toujours des positions stationnaires à l'embouchure des fjords et aux endroits où il y a changement de largeur. C'est en général entre de telles positions que le front avance ou recule: l'avance peut paraître anormale comparéc à celle des glaciers voisins n'aboutissant pas à la mer et le retrait peut être rapide. Ces particularités des glaciers de fjord peuvent être au moins partiellement expliquées par le comportement d'un glacier s'écoulant dans un fjord idéal de largeur constante: le glacier ne peut atteindre son équilibre en changeant la surface de sa zone d'ablation ou la position de son front déchargeant des icebergs; ni la zone d'ablation ni la position du front ne peuvent changer leur altitude en correlation avec les changements d'altitude de la ligne de névé.

Zusammenfassung. Fjordgletscher erreichen stationäre Lagen fast immer an Fjordmündungen oder an Stellen, wo sich die Fjordbreite ändert. Innerhalb dieser Stellen geht das Gletscherende entweder vor oder zurück. Das Vorrücken kann im Vergleich zu Festlandsgletschern anormal sein, auch der Rückgang kann katastrophal stark sein. Diese Besonderheiten von Fjordgletschern können zumindest zum Teil erklärt werden, indem man sich die Verhältnisse in einem Idealfjord von konstanter Breite überlegt. Der Gletscher kann sein Gleichgewicht nicht erreichen, indem er die Ausdehnung seines Ablationsgebiets oder die Lage seiner Kalbungsfront ändert; denn diese können ihre Höhe relativ zum Meeresspiegel im Zusammenhang mit dem Steigen und Fallen der Firnlinie nicht verändern.

\section{Observations in Alaska}

Since they were first seen, some Alaskan tidewater glaciers have suffered catastrophic recession, some have oscillated, and others have continued a slow advance: all three kinds of behaviour may occur within a comparatively small area. In some cases what appear to be the maximum post-Thermal Maximum positions have been reached during the last two centuries, but often there are massive terminal moraines of an earlier, much greater advance. Most of these are of unknown age and may thus be pre-Thermal Maximum, but in Yakutat and Icy Bays the outer moraines have been dated by ${ }^{I} \mathrm{C}$ to A.D. 970-I 290 and $600-920$ respectively. ${ }^{\mathrm{I}}$

End moraines are almost always found at the mouths of the fjords, or of branches of the fjords, or in places where these widen or are bordered by low ground; in other words, where the glacier termini could expand. After examining the characteristics and recent behaviour of some tidewater glaciers, an attempt will be made to explain this by showing theoretically that a glacier in an ideal fjord of constant width, when responding to a change in the firn limit, can only reach standstill in such a position, and will continue to advance or retreat between breaks in the width with no further change in the firn limit. Such a glacier may therefore be anomalous in its behaviour compared to glaciers on dry land in the vicinity. Most tidewater glaciers are in inlets that bear enough resemblance to this ideal example for the theory to have practical applications.

Tidewater glaciers are found from the Kenai Peninsula to the neighbourhood of Petersburg. With the exception of La Perouse Glacier which enters the open sea, all are in fjords or bays. The present state and past movements of those for which there are good maps, air photographs, and some ground observations, are described from north-west to south-east.

* This paper was written while the author was carrying out research at the American Geographical Society, New York. Ed. 


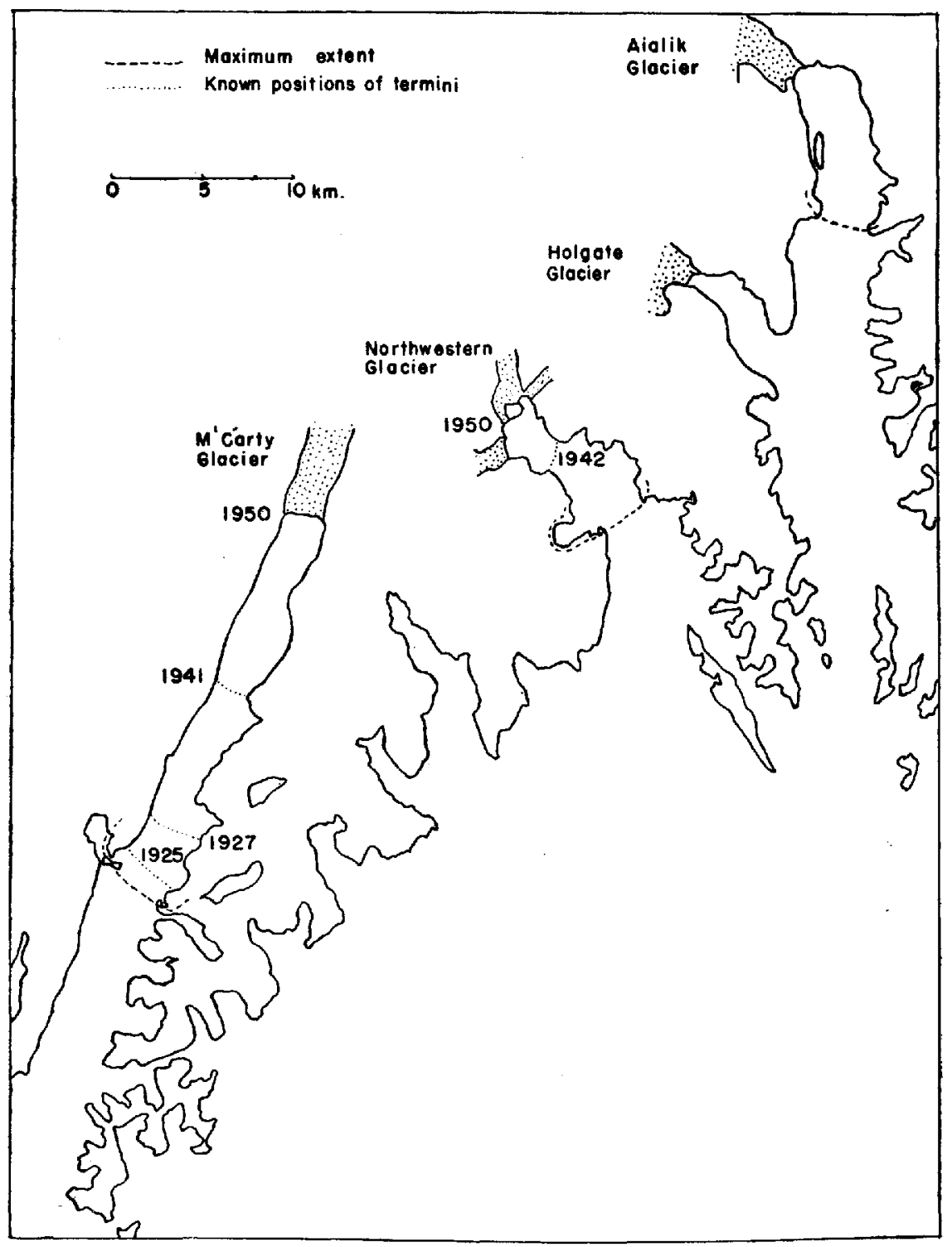

Fig. I. Tidewater glaciers of the Harding Icefield, Alaska 


\section{Glaciers of the Harding Icefield (Fig. I)}

The M'Garty Glacier is in a long, straight fjord of almost constant width, and at its maximum about $\mathrm{I} 860 \mathrm{o}^{2}$ ended where the fjord widened. Retreat was very slow at first but has tended to accelerate since.

Period
Igog-25
$1995-27$
$1927-42$
$1942-50$

Total recession, metres
6,440
1,610
9,300
10,000

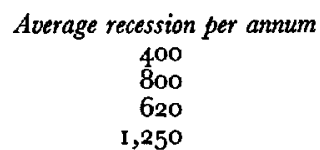

In the 25 years from 1925 to $195^{\circ}$ the total length decreased from 35 to $14 \frac{1}{2} \mathrm{~km} .{ }^{3}$

The Northwestern Glacier at the beginning of the century extended to a maximum position at a widening of the inlet, but by 1909 had withdrawn about $400 \mathrm{~m} .{ }^{4}$ From 1909 to I 942 it retreated $6 \mathrm{~km}$. and from 1942 to 1950 another $4 \mathrm{~km} .{ }^{5}$

The Aialik Glacier when first seen in Igog had almost withdrawn from the water, and has changed little since, but across the fjord at the first break in width there is an ancient terminal moraine. ${ }^{6,7}$

\section{Glaciers of Port Wells (Fig. 2)}

During the nineteenth century, some of the glaciers of Port Wells such as the Yale, Barry, Serpentine and Surprise Glaciers, reached a maximum position at the mouths of smaller inlets; others, such as the Harvard and Harriman, are still advancing into mature forest. ${ }^{8}$ Several kilometres beyond, there is a set of ancient moraines of unknown age at the mouths of College Fjord and Barry Arm. ${ }^{9}$

Meares Glacier, Unakwik Inlet (Fig. 2)

Since it was first seen in 1905 the Meares Glacier at the head of Unakwik Inlet has been advancing slowly into mature forest, while the small glaciers round the fjord have all been receding. ${ }^{10}$ There is a much older terminal moraine half-way down the fjord at a place where expansion of the terminus onto low ground was possible. ${ }^{I I}$ The front is at present narrowing slightly as it advances.

\section{Columbia Glacier, Prince William Sound}

The Columbia Glacier invaded mature forest in 1892 and again between 1917 and 1922 , since when the terminus has oscillated..$^{12}$ This maximum has occurred at a small but definite widening of the valley and at its present position the front is about one-third wider than it was $5 \mathrm{~km}$. back.

Shoup Glacier, Port Valdez

There has been little change in the position of the terminus of the Shoup Glacier since the end of the nineteenth century, when it had withdrawn to the head of its fjord and was no longer afloat. ${ }^{13}$ Outside the entrance to the fjord there is a crescentic terminal moraine, mostly submerged.

\section{Glaciers of Yakutat and Icy Bays}

The Hubbard Glacier at the head of Disenchantment Bay, which opens into Yakutat Bay, is advancing, and is now further forward than in $189{ }^{1 .}{ }^{14} \mathrm{~A}$ terminal moraine at the mouth of the fjord marks the maximum position in the eighteenth century, and another much longer moraine at the entrance to Yakutat Bay itself marks the maximum of A.D. 9701290. Icy Bay also has two terminal moraines, the older formed between A.D. 600 and 920 . Recession from the younger began about $19043^{15}$ between then and $194 \mathrm{I}$ the ice retreated $25 \mathrm{~km}$. but has remained fairly stable since. ${ }^{16}$ 


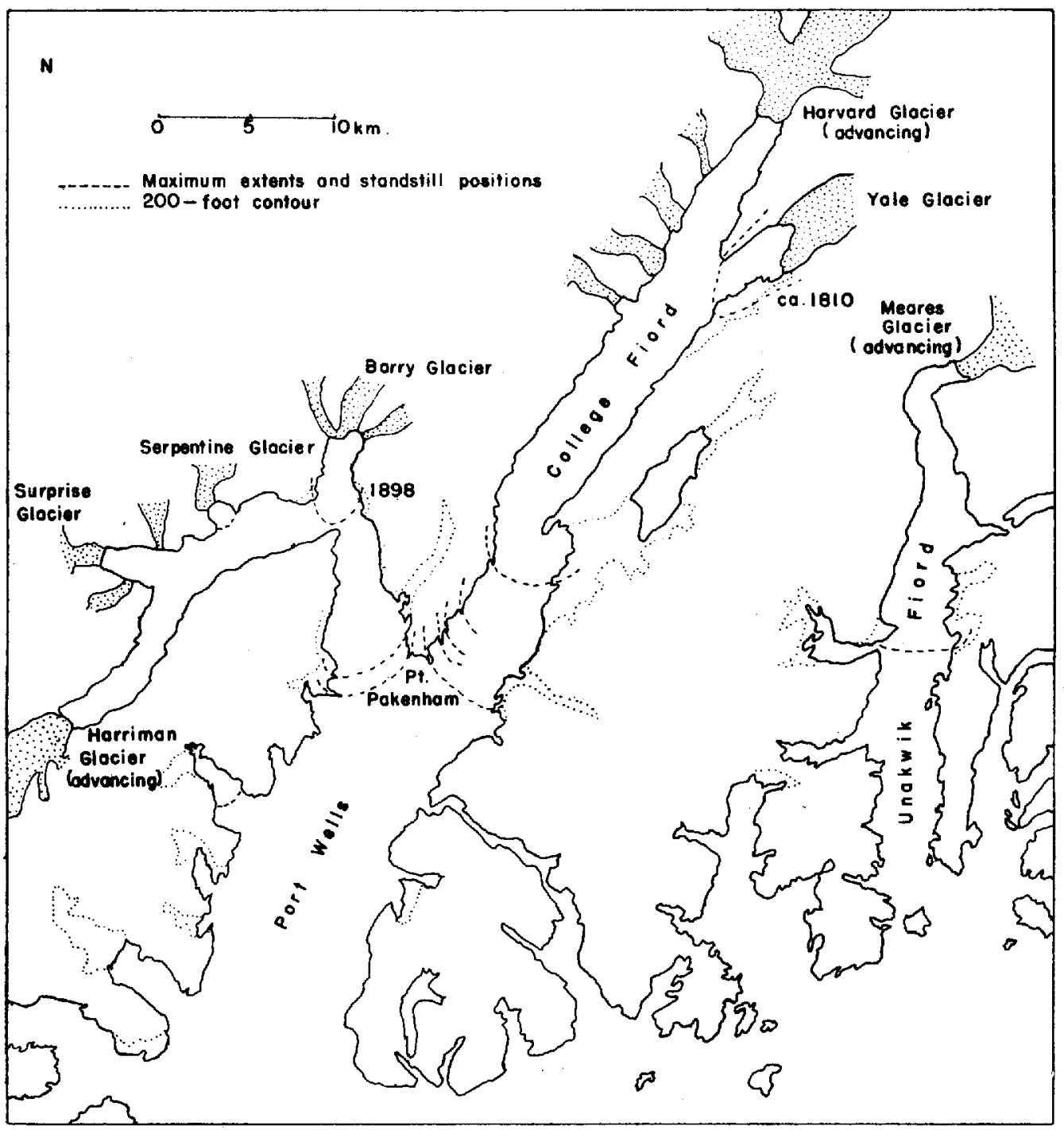

Fig. 2. Tidewater glaciers of the Port Wells area, Alaska

Glaciers of Glacier Bay (Fig. 3)

About A.D. I $75^{\circ}$ ice completely filled Glacier Bay to its mouth. By Vancouver's visit in I 794 recession had already begun and when next seen in 1879 the ice had retreated past Thlinkit Point and split into two streams. Recession continued up Reid Arm to a maximum of $\mathrm{r} 00 \mathrm{~km}$. from Icy Strait, this being the greatest recession observed anywhere in the world. Grand Pacific and Johns Hopkins Glaciers have readvanced about $\mathrm{I} \frac{1}{2} \mathrm{~km}$. since the I920's, and Muir Glacier has continued its retreat, broken by short periods of stability. ${ }^{17}$, I8, 19

Glaciers in the Holkham Bay area (Fig. 4)

Tracy and Endicott Arms, fjords opening off Holkham Bay, have massive, partly submerged terminal moraines at their mouths, about $40 \mathrm{~km}$. from the present ice fronts, and other 

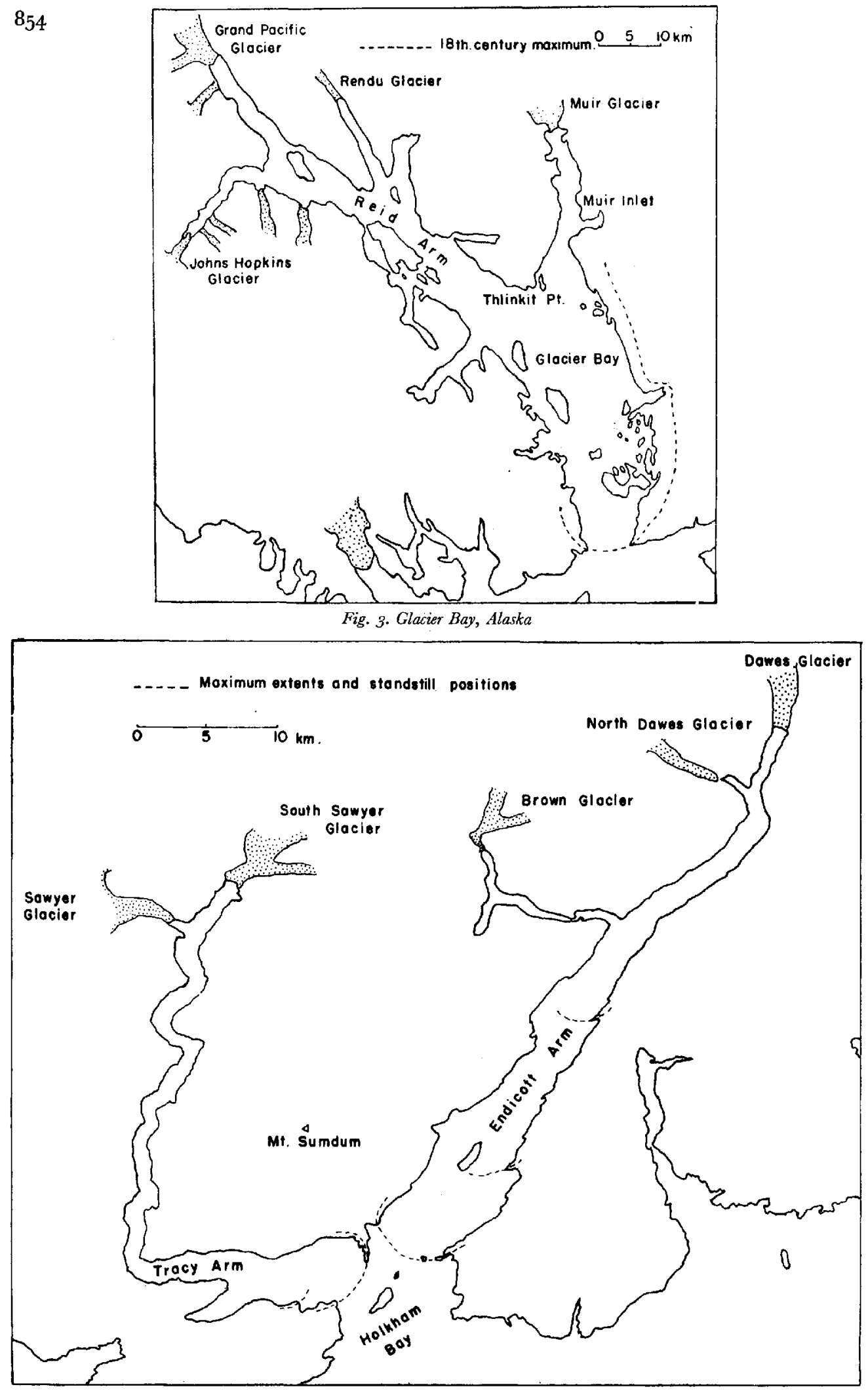

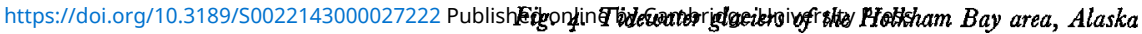


much smaller moraines are found inside Endicott Arm at breaks in the width. Since I 889 in Tracy Arm the South Sawyer has retreated about $\mathrm{I} \frac{1}{2} \mathrm{~km}$. while the Sawyer has oscillated. ${ }^{20}$ In Endicott Arm the Dawes Glacier has retreated spasmodically a total of about $5 \mathrm{~km}$. and the North Dawes about $1 \frac{3}{4} \mathrm{~km} .{ }^{2 I}$

\section{Baird Glacier, Thomas Bay}

The Baird Glacier at the head of Thomas Bay advanced from its first survey in 1887 till I 935 when it was invading mature forest. Since then the position of the terminus has changed little. ${ }^{22}$ At the entrance to the Bay, a large crescentic spit and reef appear to be a partly submerged terminal moraine.

\section{The Le Conte Glacier, Frederick Sound}

The Le Conte is the southernmost tidewater glacier in North America (lat. $5^{\circ} 5^{0^{\prime}} \mathrm{N}$.). It retreated about $3 \mathrm{~km}$. between $\mathrm{I} 893$ and $\mathrm{I} 94^{2}$; as a result, the lower part of the glacier has steepened and the active front narrowed, and from 1942 to $194^{8}$ there was no appreciable change. ${ }^{23}$ Shoals and islets outside the entrance to the bay probably mark an ancient end moraine.

\section{The Theoretical Responses of Fjord Glaciers to Changes in the Firn Limit}

\section{(1) The response to a fall in the firn limit}

A glacier in equilibrium, with its terminus near the head of a fjord of constant width (a, Fig. 5), will have its accumulation balanced by surface melting, and by calving and melting along the terminus. If the glacier is afloat, there will also be losses from undermelting, but it is unlikely that any fjord glacier in Alaska is afloat today. If the firn limit falls and the terminus advances, calving and melting along the terminus will remain constant since the fjord is of constant width, so that the glacier can reach equilibrium only by increasing the length of its ablation area, since it cannot widen. If the glacier is afloat, the area subject to undermelting will increase to a maximum and then remain more or less constant since the under-surface slopes down towards, and eventually reaches, the fjord bottom.

As the terminus advances, however, the ice at any given point behind it will thicken and eventually the ice above what was the head of the fjord may reach the firn limit (b, Fig. 5). This is a critical point because thereafter as the terminus advances the firn limit will advance an equal distance behind it as the surface slope will tend to remain the same (c, Fig. 5). In other words, if the terminus advances past this point the ablation area remains constant while the accumulation area increases with no further fall in the firn limit. The terminus will therefore continue to advance down the fjord until this widens and wastage can increase: a fjord glacier may therefore still be advancing long after others in the neighbourhood have reached equilibrium.

This effect will be enhanced by another factor. The increase of net ablation below the firn limit is almost linear; that is, a halving of the vertical distance below the firn limit will

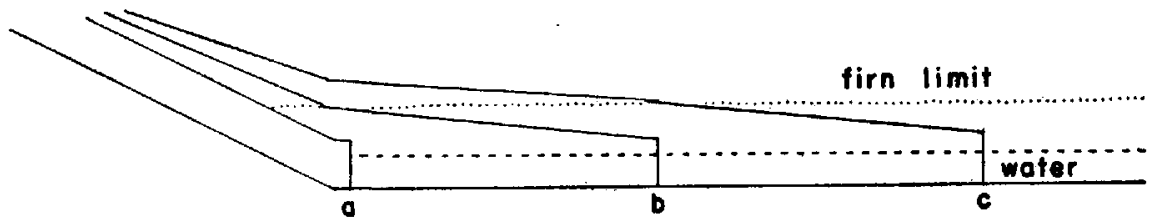

Fig. 5. A glacier advancing into a fjord. After a fall in the firn limit, a glacier advancing from a towards b will increase its ablation area, so the glacier may reach equilibrium between these points. Between $\mathrm{b}$ and $\mathrm{c}$, however, the ablation area remains the same and the accumulation area increases, so the glacier will continue to advance 
also halve the net ablation. ${ }^{24,25} \mathrm{~A}$ glacier on a hillside can respond to a fall in firn limit by advancing its terminus to a lower elevation but the terminus of a fjord glacier is always at sea level, and therefore if the firn limit falls, the vertical distance between it and the terminus will decrease. After a fall in the firn limit, the ablation area of a fjord glacier will therefore be less effective per unit area than before, and will have to be larger to suffer the same wastage. The greater the proportional fall in firn limit the greater will this effect be; in other words, for any given fall in firn limit, the effect will be greater the closer the original firn limit was to sea-level.

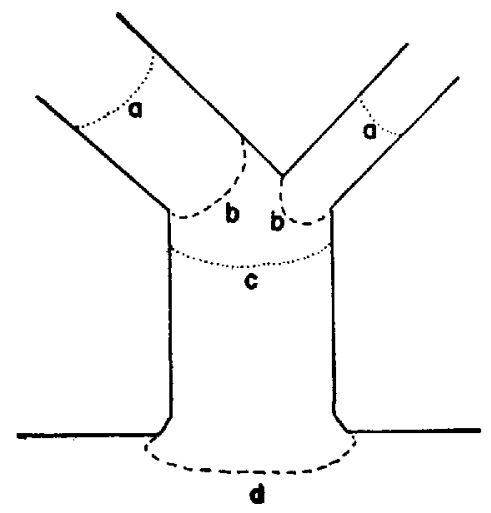

Fig. 6. Possible standstill positions (b and d) of glacier termini in a fjord system

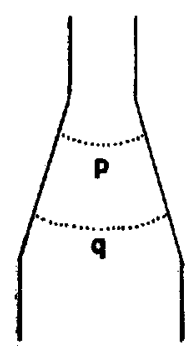

A

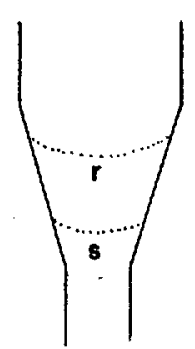

B

Fig. 7. The effect of the shape of a fjord on the behaviour of glacier termini. In Fig. $7 A$, a glacier can reach equilibrium since if it advances from $\mathrm{p}$ to $\mathrm{q}$ it will increase its wastage and if receding from $\mathrm{q}$ to $\mathrm{p}$ it will decrease its wastage. In Fig. $7 B$ a glacier advancing from $\mathrm{r}$ to $\mathrm{s}$ will decrease its wastage and accelerate its advance; if receding from $\mathrm{s}$ it will increase its wastage and accelerate its recession

In a $\mathrm{Y}$-shaped fjord system after a fall in the firn limit, glaciers may advance along the arms of the $\mathrm{Y}$ (a, Fig. 6) and reach equilibrium as their termini expand into the main fjord (b, Fig. 6). They may remain in this position indefinitely if the termini do not come into contact with each other; this is apparently what happened in Port Wells and Holkham Bay (Figs. 2 and 4). If the termini start to coalesce, however, the total calving losses will decrease and the combined glacier will advance down the main fjord (c, Fig. 6) to its mouth, where equilibrium is restored (d, Fig. 6).

This must have happened in Glacier Bay where, however, another factor was also operating. All fjords differ more or less from the ideal example of constant width, and the glaciers in them will be more stable if they narrow towards their heads, when the wastage will increase as the glacier advances (Fig. $7 \mathrm{~A}$ ), less stable if they widen, for then the wastage 
will decrease (Fig. $7 \mathrm{~B}$ ). Glacier Bay widens and in such a bay since any advance will decrease and any retreat increase the wastage, once a terminus is moving forward or backward it will tend to continue in that direction even against contrary changes in the firn limit. It is probable that the firn limit in Glacier Bay had already started to rise before the glacier had reached its maximum otherwise equilibrium would not have been reached when the terminus was at the very narrowest part of the bay, but the advance was able to continuc to this point as the calving front became progressively narrower.

\section{(2) The response to a rise in the firn limit}

A glacier may be advancing down a fjord when the firn limit starts to rise; if it is fairly near the head of the fjord and has a moderately steep surface slope, a small rise in the firn limit may still leave it with a positive regimen, and it will continue to advance though more slowly than before. This may account for the continued advance of the Harvard and Meares Glaciers. A glacier with its terminus further from the head of the fjord, however, is more vulnerable to a rise in the firn limit because of its lower surface gradient. In the same area, therefore, slight differences in surface profile may result in very different responses to the same rise in firn limit.

Unlike a glacier on land, particularly one well protected with surface moraine, a glacier afloat cannot stagnate in situ as it has a calving front: the terminus must respond at once to any decrease in the supply of ice. This is well illustrated by the great retreats of the ice fronts in Icy and Yakutat Bays while the Malaspina Glacier in between has changed very little in extent.

If a fjord glacier has reached a position of equilibrium before the rise in firn limit, with its terminus expanded outside the mouth of a fjord, it will retreat slowly into the fjord, thus reducing the wastage from calving. After it has withdrawn into the fjord, however, its behaviour will depend on the configuration of the fjord as it did when it was advancing. In an ideal fjord of constant width the calving losses, and undermelting losses if any, remain constant, and the ablation area will grow in both size and effectiveness per unit area as the gap between firn limit and terminus widens and the glacier surface is lowered. The retreat will therefore accelerate until, as the terminus withdraws towards the head of the fjord, the ablation area decreases as the surface steepens. A good example is seen in the behaviour of the M'Carty Glacier, which has been receding at an accelerating rate up a fjord of almost constant width. Equilibrium may not be reached till the terminus has withdrawn onto the land where there are no calving losses. The retreat can be much more rapid than the advance as the equivalent of several years' accumulation may be dissipated in one year.

In a fjord that widens towards its head a glacier that has started to retreat will tend to continue an accelerating retreat as its wastage increases (Fig. $7 \mathrm{~B}$ ). An example is Glacier Bay where, as has been suggested above, the maximum position was reached after the firn limit had started to rise. With the firn limit continuing to rise, the stage was set for a catastrophic recession as ablation would have increased as the widening ice front withdrew up the bay.

In fjords that narrow towards their heads, recession is likely to be slow and unspectacular.

\section{Conclusions}

The known behaviour of Alaskan fjord glaciers agrees well with that to be expected according to theory. The spectacular retreats and anomalous advances in time of rising firn limits have been at least partially explained. Since firn limits have been rising since the glaciers were first seen there is no first-hand knowledge of their behaviour when firn limits were falling. Terminal moraines, however, showing where equilibrium was reached after a period of advance, are usually found where the termini could expand.

Glaciers in narrow, level-floored valleys would respond to a fall in the firn limit in a 
similar manner to fjord glaciers, but after a rise in firn limit they could stagnate in situ as they have no calving termini.

MS. received 3 August 1960

\section{REFERENGES}

I. Plafker, G., and Miller, D. J. Glacial features and surficial deposits of the Malaspina district, Alaska. U.S. Geological Survey. Miscellaneous Geologic Investigations, Map I-27 I, I958.

2. Grant, U. S., and Higgins, D. F. Coastal glaciers of Prince William Sound and Kenai Peninsula. U.S. Geological Survey Bulletin 526, 1913 , p. 63.

3. Field, W. O., and others. Geographic study of mountain glaciation in the Northern Hemisphere. New York, American Geographical Society, 1958, pt. 2a, ch. 4, p. 17.

4. Grant, U. S., and Higgins, D. F. op. cit., p. 6 r.

5. Field, W. O., and others. op. cit., pt. $2 a$, ch. 4 , p. 16.

6. Grant, U. S., and Higgins, D. F. op. cit., p. $5^{8 .}$

7. Field, W. O., and others. op. cit., pt. 2a, ch. 4, p. 15.

8. Ficid, W. O., and others. op. cit., pt. $2 \mathrm{a}$, ch. 3, p. 35,39 .

9. Tarr, R. S., and Martin, L. Alaskan glacier studies. Washington, D.C., National Geographic Society, 1914 , p. 346.

10. Field, W. O., and others. op. cit., pt. 2a, ch. 3, p. 33 .

I I. Tarr, R. S., and Martin, L. op. cit., p. 293.

I 2. Field, W. O., and others. op. cit., pt. $2 \mathrm{a}_{\text {; }}$ ch. 3 , p. $3^{2}$.

I3. Field, W. O., and others. op. cit., pt. $2 \mathrm{a}$, ch. 3, p. $3^{2}$.

I4. Field, W. O., and others. op. cit, pt. $2 \mathrm{a}$, ch. 2, p. 21.

I5. Plafker, G., and Miller, D. J. op. cit.

I6. Field, W. O., and others. op. cit., pt. 2a, ch. 3 , p. 11.

I 7. Field, W. O., and others. op. cit., pt. 2a, ch. 2, p. I I.

18. Cooper, W. S. The problem of Glacier Bay, Alaska; a study of glacier variations. Geographical Review, Vol. 27 , No. I, I937, p. 37-6r.

I9. Field, W. O. Glacier recession in Muir Inlet, Glacier Bay, Alaska. Geographical Review, Vol. 37, No. 3, I947, p. 369-99. Also personal communication.

20. Field, W. O., and others. op. cit., pt. 2a, ch. I, p. 55 .

21. Field, W. O., and others. op. cit., pt. 2a, ch. I, p. 52.

22. Field, W. O., and others. op. cit., pt. 2a, ch. I, p. 49.

23. Field, W. O., and others. op. cit., pt. $2 \mathrm{a}$, ch. I, p. 48.

24. Renaud, A. Observations on the surface movement and ablation of the Grorner Glacier (Switzerland). Journal of Glaciology, Vol. 2, No. I I, I952, p. 57.

25. Nielsen, L. E. Preliminary study on the regimen and movement of the Taku Glacier, Alaska. Bulletin of the Geological Society of America, Vol. 68, No. 2, 1957, p. 178. 